\title{
MODELLING AND CALCULATION OF ADAPTIVE DEVICES OF AUTOMATION, CONTROL AND PROTECTION FOR INTELLECTUAL ELECTRIC GRID IN SCILAB FREEWARE COMPUTER MATHEMATIC PACKAGE
}

\author{
G.I. Volovich, South Ural State University, Chelyabinsk, Russian Federation, \\ g_volovich@mail.ru, \\ E.V. Solomin, South Ural State University, Chelyabinsk, Russian Federation, \\ nii_uralmet@mail.ru, \\ I.G. Topolskaya, South Ural State University, Chelyabinsk, Russian Federation, \\ irina_topol71@mail.ru, \\ D.V. Topolsky, South Ural State University, Chelyabinsk, Russian Federation, \\ topol69@mail.ru, \\ N.D. Topolsky, South Ural State University, Chelyabinsk, Russian Federation, \\ ntopolsky@mail.ru
}

In this paper we studied the possibilities of adaptation of Scilab freeware computer mathematic package to the solution of special calculation problems are studied. We modeled and calculated the family of adaptive devices of automation, control and protection for smart/intellectual electric grids including renewable energy sources. We studied the possibilities of Scilab package for sequential calculating using a big number of algebraic functions, solving the systems of linear algebraic equations, analyzing of results, solving the tasks of optimization, building 2D and 3D function diagrams, etc. All calculated solutions obtained from Scilab, were analysed in comparison with the similar solutions calculated in MathCAD. The results confirm the relevance of using the Scilab package for these purposes and demonstrate some of its advantages in education, scientific research and electric engineering calculations.

Keywords: computer mathematics; programming; modelling in Scilab; freeware software; electric engineering calculation.

\section{Introduction}

It is almost impossible to imagine a modern science today without the extensive use of mathematical modelling. This method of study, design and engineering combines many advantages of both theory and experiment. Operating with the model but not with the real object (phenomenon, process), allows relatively quickly with significant costs reduction investigating its properties and behavior in all conceivable situations (the benefits of theory).

At the same time basing on the advanced computational methods and technical capabilities of computers, the computer experiments with the models of objects may help to study objects in sufficient details and in depth which is not possible in purely theoretical approaches (the benefits of the experiment). Therefore the methodology of mathematical modelling presents rapidly developing and embracing new areas, including intellectual/smart electric grids and renewable energy devices. 


\section{The Relevance of Modelling Tool Selection}

The development of science depends mainly on the enhancement of quality of education, which is in turn possible on the basis of new information technologies.

In recent years, Russia has undertaken a number of efforts for the development and implementation of freeware software in educational institutions. The main advantage of freeware software for the purpose of education is to have a legal basis to freely explore the documented source code of freeware software for computer and modify it, including the created on its own design basis. For the education purpose it is necessary to provide both teachers and students with the opportunity of choice between freeware and proprietary software. In this context, the purpose of our study was a testing of ability of offering the freeware software in relation to the mathematical modelling and calculation of electric engineering systems.

Modelling is one of the most common methods of research which combines the capabilities of theory and practice. Simulation is also relevant particularly for solving the electrical problems [1,2]. Development of methodology for modelling and analysis of electrical systems using freeware software, is of great practical importance and relevance.

The simulation results mostly depend on software type. Mathematical packages are widely used in the modelling. There is a big number of computer mathematics systems on the market. All of them have great opportunities, advantages and also disadvantages. The process of involvement of the students into research meets the major drawback of these packages - purchasing a license for their use, which often makes scientific research more difficult and expensive [3].

One of the most popular open source mathematical package is Scilab. Scilab is designed for engineering and scientific calculations. In terms of its features Scilab package is comparable to the known Mathcad mathematical package, with the interface similar to Matlab. Versions of Scilab for different operating systems: Linux, Windows, MacOS are available.

Similar to Matlab the Scilab as the system itself, is primarily intended for numerical computations and works with matrices. Main features of Scilab: operating with elementary and special functions used in mathematics (approximation of elliptic integrals, Bessel functions), set of tools for conventional and matrix polynomials; tools for building and manipulating arrays (vectors, matrices, etc.) and hundreds of mathematical functions with the possibility of adding new ones including written in different languages $(\mathrm{C}, \mathrm{C}++$, Fortran); 2D and 3D graphics, animation, differential and differential optimization, stats and much more [4]. The package also includes Scicos - a tool for editing block diagrams and simulations (similar to Matlab Simulink package) [5]. There is the opportunity of working with LabVIEW in Scilab. Powerful programming language with support of objects built in Scilab allows not just creating an ordinary program for automation of calculations, but also seeing visual applications running in the Scilab environment. The main object in the environment of Scilab is a graphical window. The correct version of Scilab can always be downloaded from the official website.

\section{Results}

During the testing of the Scilab package performing the modelling and analysis of electrical systems, a number of problems were solved. Design solutions were obtained 
in Scilab for direct current (DC) electrical circuits with DC power supply, complex DC electrical circuits, single-phase circuits with sinusoidal current. In addition to that we also designed and built the models of mechanical characteristics of DC machines (see Fig. 1). All analysis solutions obtained for Scilab were analyzed in comparison with similar solutions obtained for Mathcad. The results appeared to be identical.

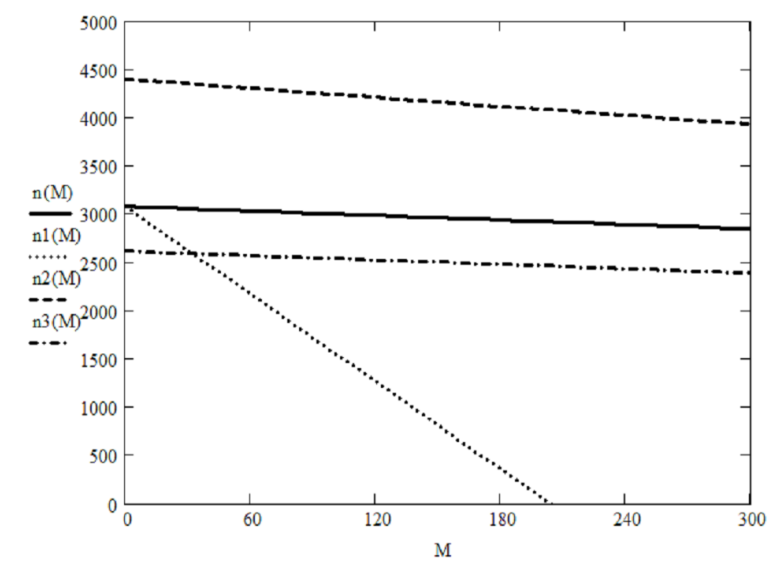

Fig 1. The results of calculation of the modeled mechanical characteristics of DC electric machine

On the top of everything a number of models of renewable energy sources was developed: the model output with Chelyabinsk based landfill of municipal solid waste (MSW) from the equation of the reaction kinetics of gas formation of the first degree and the model of Tabasaran-Rettenberger as well as active and reactive hydraulic turbines, model of biogas plant for farming, and others. These models actually are the set of sequential calculations. Fig. 2 shows the modelling results of parameters of new Chelyabinsk landfill of MSW.

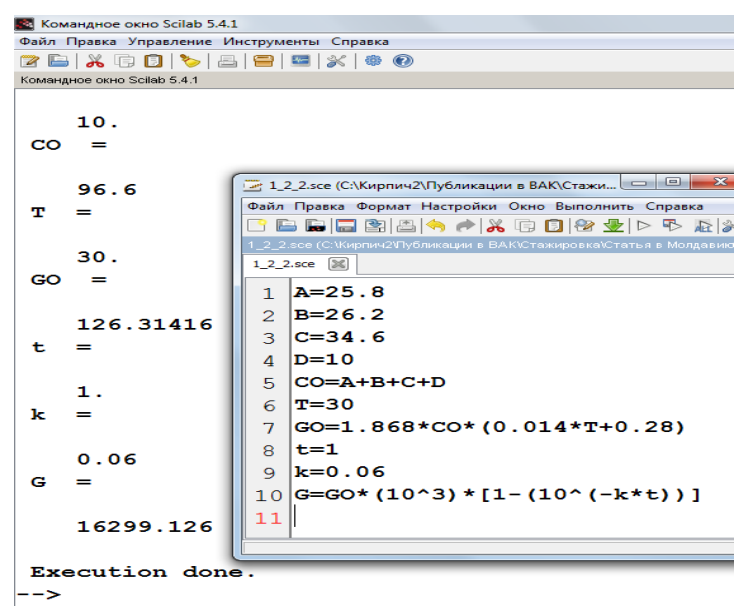

Fig 2. The modelling results of parameters of new Chelyabinsk landfill of MSW.

We also analysed the thermic stability of circuits of digital measuring current transformer. To solve this task we programmed and solved a sequence of linear algebraic equations. The results of modelling are presented in Fig. 3. 


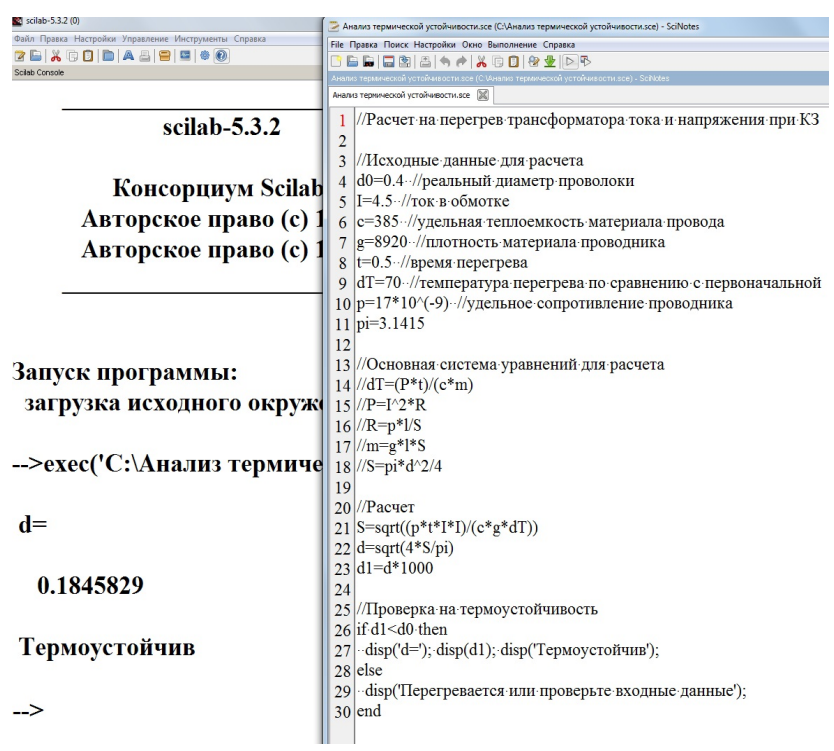

Fig 3. Analysis of thermic stability of circuits of digital measuring current transformer

One of the types of problems solved in Scilab, is the optimization task. In this area we considered the problem of linear programming, where we were required to find the values of variables $\mathrm{x} 1, \mathrm{x} 2, \mathrm{x} 3, \mathrm{x} 4$, when the objective function reaches its maximum value and the number of constraints is satisfied. For solving these problems in Scilab there is a function called linpro. The results of solving optimization tasks are presented in Fig. 4.

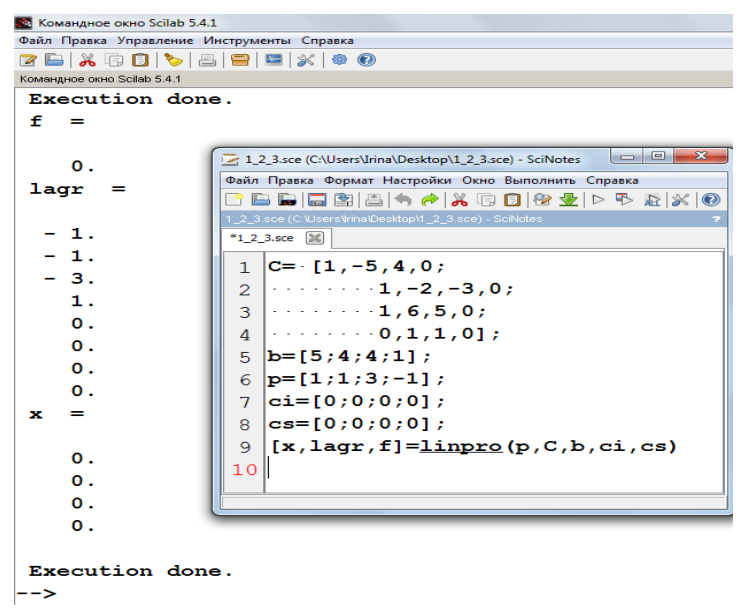

Fig 4. The results of solving optimization problems

The model of asynchronous electric drive had the range of possible variations of time constants. It was studied for the development of adaptive controller of the drive. One of modelling results is the surface, which characterizes the variation of electromagnetic time constants of electric drive (Fig. 5).

Conclusion. The study of the possibility of using freeware software Scilab package for mathematical modelling and calculation of electrical systems in general, as well as in particular of automation, control and protection of intellectual electric grids, shows its suitability for this purpose. We obtained positive experience of its usage in the process of 


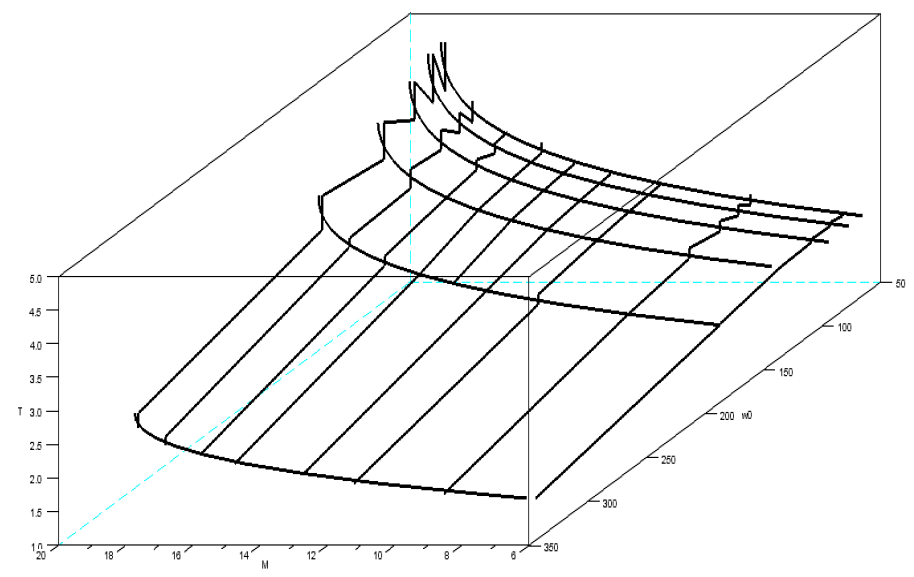

Fig 5. The variation of electromagnetic time constants of the asynchronous electric drive

study of physical basis of collecting the information, methods and means of measurement, as well as solving optimization tasks. We found its capacity not inferior than of the licensed mathematical packages in solving the most tasks. It is correct to confirm the benefits of Scilab computer software package as of freely distributed program for education and science. All this shows the relevance of extending the scope of use of Scilab package.

This work was supported in part by the R.F. Ministry of Education under Grant 14.576.21.0047 of 22 August 2014 (ID: RFMEFI57614X0047).

\section{References}

1. Savinova D.V. Application of Imitation Modelling in Electric Engineering Theoretical Base Course Study. Bulletin of the South Ural State University. Series: Energy, 2007, no. 12, pp. 58-60. (in Russian)

2. Klinachev N.V., Klinacheva N.V. Presentation of Mathematic Models of Electric Machines Using Jigrein Software Graphic Language. Bulletin of the South Ural State University. Series: Energy, 2008, no. 26 (10), pp. 46-49. (in Russian)

3. Kirpichnikova I.M., Topolsky D.V, Topolskaya I.G. Relevance of Using the Freeware Software in Modelling of Electric Engineering Systems Containing Renewable Energy Sources. Actual Items of Science: Materials of VII International Scientific-practical Conference (25.01.2013), Moscow, 2013, pp. 65-69.

4. Alekseev E.P., Chesnokova O.V., Rudchenko E.A. [Scilab: Solution of Engineering and Mathematical Tasks]. Moscow, ALT Linux, BINOM. Laboratory of knowledge, 2008. 269 p. (in Russian)

5. Campbell S.L., Chancelier J.-P., Nikoukhah R. [Modelling and Simulation in Scilab/Scicos]. Available at: http://www.iitg.ernet.in/trivedi/Downloads/scilab/book.pdf (accessed 6 September 2014).

Received June 18, 2015 


\title{
МОДЕЛИРОВАНИЕ И РАСЧЕТ АДАПТИВНЫХ
} УСТРОЙСТВ АВТОМАТИКИ, УПРАВЛЕНИЯ И ЗАЩИТЫ ДЛЯ ИНТЕЛЛЕКТУАЛЬНЫХ ЭЛЕКТРИЧЕСКИХ СЕТЕЙ В СВОБОДНО РАСПРОСТРАНЯЕМОМ ПАКЕТЕ КОМПЬЮТЕРНОЙ МАТЕМАТИКИ SСILАВ

\author{
Г.И. Волович, Е.В. Соломин, И.Г. Топольская, Д.В. Топольский, \\ Н.Д. Топольский
}

В работе исследованы возможности адаптации свободно распространяемого пакета компьютерной математики Scilab для решения специализированных вычислительных задач. Для этого в Scilab осуществлено моделирование и расчет ряда адаптивных устройств автоматики, управления и защиты для интеллектуальных электрических сетей, включая возобновляемые источники энергии. Были исследованы возможности пакета Scilab для выполнения последовательных расчетов с использованием большого числа математических функций, решения систем линейных алгебраических уравнений, анализа результата, решения задач оптимизации, построения двумерных и трехмерных графиков функций и др. Bce расчетные решения, полученные для Scilab, были проанализированы в сравнении с аналогичными решениями, полученными для Mathcad. Полученные результаты подтверждают возможность использования Scilab для указанных целей и демонстрируют ряд преимуществ при применении пакета в обучении на электротехнических специальностях и проведении научных исследований.

Ключевые слова: компьютерная математика; программирование; моделирование Scilab; свободно распространяемое ПО; электротехнические расчеты.

\section{Литература}

1. Савинова, Д.В. Применение имитационного моделирования при изучении курса ТОЭ/ Д.В. Савинова // Вестник ЮУрГУ. Серия: Энергетика. - 2007. - №12. - С. 58-60.

2. Клиначев, Н.В. Представление математических моделей электрических машин с помощью графического языка программы Jigrein / Н.В. Клиначев, Н.В. Клиначева // Вестник ЮУрГУ. Серия: Энергетика. - 2008. - Вып. 10. - №26. - С. 46-49.

3. Кирпичникова, И.М. Актуальность использования свободного программного обеспечения при моделировании электротехнических систем, содержащих возобновляемые источники энергии / И.М. Кирпичникова, Д.В. Топольский, И.Г. Топольская // Актуальные вопросы науки: Материалы VII Международной научно-практической конференции (25.01.2013). - М.: Спутник +, 2013. - С. 65-69.

4. Алексеев, E.P. Scilab: Решение инженерных и математических задач / Е.P. Алексеев, O.В. Чеснокова, Е.А. Рудченко. - М.: ALT Linux; БИНОМ. Лаборатория знаний, 2008. 269 c.

5. Campbell, S.L. Modelling and Simulation in Scilab/Scicos / S.L. Campbell, J.-P. Chancelier, R. Nikoukhah. - URL: http://www.iitg.ernet.in/trivedi/Downloads/scilab/book.pdf (6 сентября 2014).

Георгий Иосифович Волович, доктор технических наук, профессор, кафедра «Системы управления», Южно-Уральский государственный университет (г. Челябинск, Российская Федерация), g_volovich@mail.ru. 
Евгений Викторович Соломин, доктор технических наук, профессор, кафедра «Электротехника и возобновляемые источники энергии», Южно-Уральский государственный университет (г. Челябинск, Российская Федерация), nii_uralmet@mail.ru.

Ирина Геннадьевна Топольская, ассистент, кафедра «Электротехника и возобновляемые источники энергии», Южно-Уральский государственный университет (г. Челябинск, Российская Федерация), irina_topol71@mail.ru.

Дмитрий Валерианович Топольский, кандидат технических наук, доцент, кафедра «Электротехника и возобновляемые источники энергии», Южно-Уральский государственный университет (г. Челябинск, Российская Федерация), topol69@mail.ru.

Никита Дмитриевич Топольский, студент, кафедра «Электронновычислительные машины», Южно-Уральский государственный университет (г. Челябинск, Российская Федерация), ntopolsky@mail.ru.

Поступила в редакцию 18 июня 2015 г. 